\title{
A study of ethical perspective towards tax evasion in Sri Lanka
}

\author{
Wijerathna A.G.H.S.K ${ }^{1}$ \& Perera H.A.P.L ${ }^{2}$ \\ ${ }^{12}$ Department of Accountancy, University of Kelaniya, Sri Lanka
}

\begin{abstract}
Tax evasion is a major problem in developing countries like Sri Lanka. Tax revenue is one of the main sources of government revenue. Government has to face difficulties of funding the government projects and paying for government expenditure when tax payers do not pay or under pay taxes. This study is aimed at identifying the ethical perspective of Sri Lankans towards tax evasion. Further, this study is also aimed at analyzing tax evasion based on several demographic characteristics and identifying the strongest arguments that are in favor and against of tax evasion from an ethical point of view. Data was collected from 50 tax payers and 50 non-tax payers through a questionnaire and analyzed. Based on the analysis conducted, it was identified that the strongest argument which is in against of tax evasion is, "tax evasion is ethical if everyone is doing it". Further, the strongest argument which is in favor of tax evasion is, "tax evasion is ethical even if a large portion of money collected is spent on projects that do benefit the tax payer". The findings if this study would be useful for the government in order to take actions to improve the tax collection from Sri Lankans.
\end{abstract}

Keywords - Ethics, Sri Lanka, Tax Evasion

\section{Introduction}

Many studies have been done on tax compliance. When compared to that there are few number of studies that have been done on non-compliance with tax. Out of those studies on non-compliance with tax, a few number of studies have been done on tax evasion from an ethical perspective. Most of the studies have been done on tax evasion from a finance perspective.
Simply the term "tax evasion" refers to the illegal non-payment or underpayment of tax. Tax evasion is an intentional illegal behavior leading to a direct violation of tax law to escape the payment of tax (Gabor, 2012). Tax evasion is a violation of tax law, whereby the taxpayer refrains from reporting income which is taxable (Sandmo, 2005). Tax evasion represents the illegal practices to escape from 
taxation that can occur in an isolated incident within the activity or in the informal or the shadow economy where the whole activity takes place in an informal manner.

Tax evasion can be identified as a crucial problem for many countries as it affects to the development of the country. Taxes are essential for the development of a country. In most of the countries, tax system can be identified as the primary source of funding for a wide range of social and economic programs. Therefore, taxes are important to finance public services and fulfill a county's basic functions.

Literature suggests that level of tax evasion is high in developing countries rather than in developed countries (Sezgin, Yildiz, \& Ayyildiz, The Ethics of Tax Evasion: A Comparative Study of Turkey and Kyrgyzystan, 2011).Tax evasion in most developing countries is extensive. This issue is intensify by the fact that many of these countries have not made an effort to measure the ethical reasons for the tax evasion (Fagbemi, Uadiale, \& Noah, 2010).

In Sri Lanka, the total government revenue in 2016 is Rs. 231.2bn. Out of that Rs.123.3bn is non tax revenue and Rs. 107.9 bn is tax revenue. As a percentage non tax revenue is $53.3 \%$ from total government revenue and tax revenue is $46.7 \%$ from total government revenue. This indicates that tax revenue plays a significant role in government revenue. In 2014, 6000 cases of tax evasion was identified in Sri Lanka (Machinayake, 2014). This indicates that Sri Lanka has serious tax evasion problem which should be addressed with appropriate government policies.

In 2007, McGee W. Robert and Smith R. Sheldoncarried out a study on tax evasion with the objective of determine the strength of 18 arguments which justify the tax evasion as ethical. The study has been done with the use of seven-point Likert scale (McGee \& Smith, Ethics, Tax Evasion, Gender and Age: An Empirical Study of Utah Opinion , 2007). The results, of this study conclude that in most situations women are more opposed to tax evasion than the men. Furthermore, the results of this study also indicates that people become more opposed to tax evasion as they get older. The finding of the women are more opposed to tax evasion than men is quite conflicting as the results of some other studies concluded that men are more opposed to tax evasion than women (Barnett \& Karson, 1987; Weeks, Moore, McKinney, \& Longenecker, 1999). Some studies have found that there is no significant difference in the gender towards the tax evasion (McGee \& Bernal, The Ethics of Tax Evasion: A Survey of Business Students in Poland, 2006; McGee \& 
Simon , 2006; McGee \& Noronha, The Ethics of Tax Evasion: A Comparative Study of Guangzhou (Southern China) and Macau Opinion, 2007).

Furthermore, there are arguments which support the Tax Evasion. The main argument that justify the tax evasion is, tax evasion is ethical if the government is corrupted or oppressive or where funds that are collected as tax revenue is spent on disapproved projects or engaged in human rights abuses (McGee \& Benk, The ethics of tax evasion: a study of Turkish opinion, 2011). The same results have been in another study carried out in China (McGee \& Guo, A survey of law, business and philosophy students in China on the ethics of tax evasion, 2007).

The problem of Tax Evasion could be addressed through several different ways. Effective tax audits, using information technology, may be needed to ensure that tax evasion is reduced. In addition, improving favorable attitudes towards the tax may also lead to reduction of Tax Evasion. This could be done through conducting effective communication programs with the tax payers which include, seminars and public awareness programs(Alleyne \& Harris, Antecedents of taxpayers' intentions to engage in tax evasion: evidence from Barbados, 2016).
In order to address the research problem, the questions of is the tax evasion perceived as ethical?, what is the strongest argument which is in favor and against of tax evasion from an ethical perspective?, and is the ethical perspective on tax evasion differ based on different demographic characteristics?, would be incorporated. The objectives of this study are; determine extent which tax evasion is considered as ethical, determine the argument that are there in favor and against on tax evasion from an ethical point of view, and analyze tax evasion based on several demographic characteristics. These demographic characteristics include, gender, age, religion marital status, academic qualification, and major of study. Through this objective it is intended to determine whether different sub groups in the society have different views on tax evasion.

The current study is mainly aimed at determining the ethical perspective of Sri Lankans towards tax evasion. Identification of ethical reasons is utmost important to identify the methods to avoid tax evasion.

\section{Methodology}

\subsection{Population and the sample}

The population of this study is, all the Sri Lankans. The total sample of this study 
is 120 Sri Lankans. The sample is consisted of 60 undergraduates and 60 tax payers in Sri Lanka.

The reason to consider undergraduates in the sample is to employ a sample that would provide an unbiased opinion on tax evasion. As the study is based on obtaining the responder's opinion, a sample that would not provide bias opinion has to be selected. Undergraduates are not employed, and therefore, they are not included to the population who pays Income Tax. Moreover, even some of them are employed, they do not earn a salary which is entitled for Income Taxes. Therefore, it is more likely that they will provide an unbiased opinion on tax evasion. Furthermore, as this sample will be future business leaders and political leaders of Sri Lanka and therefore, provide their own ideas on tax evasion that is related with their future behavior.

The reason to employ tax payers in the sample is to obtain the actual tax payers' opinion on tax evasion. As actual payers are people who affect by the tax system in Sri Lanka their opinion is more important for the study.

\subsection{Data collection method}

Primary data collection method has been used in this study. The appropriate primary data collection methods for this study is, questionnaire method. A questionnaire was developed and distributed among the selected sample. The questionnaire is consisted of 22 questions. It is mainly divided in to two categories as Section A and Section B.

Section A was designed to obtain the information about demographic characteristics of the respondents. Questions that have been asked in this section include; gender, age, religion, marital status, academic qualifications, major of studies and whether the responder has knowledge on taxation.

Section Bisconsistedof 15 statements. "Five Point Likert Scale" had been used to obtain the responders opinion on Tax Evasion. Under this the responders have been asked to place an appropriate number in the space provided to indicate the extent of their agreement or disagreement with each statement that has been provided. The questionnaire was developed based on the prior researches that have been done on Tax Evasion (McGee \& Benk, The ethics of tax evasion: a study of Turkish opinion, 2011; Nasadyuk \& McGee, 2006; McGee \& Guo, A survey of law, business and philosophy students in China on the ethics of tax evasion, 2007; McGee, Aljaaidi, \& Musaibah, The Ethics of Tax Evasion: A Survey of Administrative Sciences' Students in Yemen, 2012; Sezgin, Yildiz, \& Ayyildiz, 2011). 
To ensure the reliability and the validity of the research instrument, it was piloted and adjusted accordingly with correct wording and logical ordering of the questions.

The questionnaire was distributed among a sample of 120 . Out of that 100 usable responses were selected for the analysis.

\section{Results}

\subsection{Descriptive analysis - Descriptive statistics}

\subsubsection{Summary of responses}

The table 3.1 lists all 15 statements that were specified in the questionnaire with their mean scores. The mean score for all 18 statements is, 3.3760. When considering this mean score with the 5 point likert scale of 1 to 5 , this overall mean score of 3.3760 indicates that Sri Lankans perceive tax evasion as unethical. Moreover, when analyzing the table 4.1 , it can be observed that some statements have a higher mean score than other statements and some statements have a lower mean score than other statements. This indicates that some arguments are strongly against tax evasion and some arguments are strongly in favor of tax evasion.

\begin{tabular}{|c|l|c|}
\hline \multicolumn{2}{|l|}{ Table 3.1Summary of Responses } & Mean \\
\hline No & \multicolumn{1}{|c|}{ Statement } & 3.36 \\
\hline 1 & Tax Evasion is ethical if Tax Rates are too high & 3.68 \\
\hline 2 & Tax evasion is ethical even if tax rates are not too high, because the government is \\
not entitled to take as much as from me as tax & 2.67 \\
\hline 3 & Tax evasion is ethical if the tax system is unfair & 2.38 \\
\hline 4 & Tax evasion is ethical if a large portion of the money collected is wasted & 3.65 \\
\hline 5 & Tax evasion is ethical even if most of money collected is spent wisely & 3.32 \\
\hline 6 & $\begin{array}{l}\text { Tax evasion is ethical if a large portion of money collected is spent on projects that I } \\
\text { morally disapprove of }\end{array}$ & 3.69 \\
\hline 7 & $\begin{array}{l}\text { Tax evasion is ethical even if a large portion of money collected is spent on worthy } \\
\text { projects }\end{array}$ & 3.84 \\
\hline 8 & $\begin{array}{l}\text { Tax evasion is ethical if a large portion of money collected is spent on projects that } \\
\text { do not benefit me }\end{array}$ & \multirow{2}{*}{} \\
\hline
\end{tabular}




\begin{tabular}{|c|l|c|}
\hline 9 & $\begin{array}{l}\text { Tax evasion is ethical even if a large portion of money collected is spent on projects } \\
\text { that do benefit me }\end{array}$ & 3.93 \\
\hline 10 & Tax evasion is ethical if everyone is doing it & 4.01 \\
\hline 11 & $\begin{array}{l}\text { Tax evasion is ethical if a significant portion of money collected winds up in the } \\
\text { pockets of corrupt politicians or their families and friends }\end{array}$ & 2.55 \\
\hline 12 & Tax evasion is ethical if the probability of getting caught is low & 3.69 \\
\hline 13 & $\begin{array}{l}\text { Tax evasion is ethical if some of the proceeds go to support a war that I consider to } \\
\text { be unjust }\end{array}$ & 3.22 \\
\hline 14 & Tax evasion is ethical if I can $\square \mathrm{t}$ afford to pay & 2.95 \\
\hline 15 & Tax evasion is ethical even if it means that if I pay less, others will have to pay more & 3.70 \\
\hline Average Score & 3.38 \\
\hline \multicolumn{2}{|l}{ Note: Overall Scores (1= Strongly Agree, 5= Strongly Disagree) } \\
\hline
\end{tabular}

\subsubsection{Ranking of statements}

The mean score of each statements were ranked from weakest to strongestto identify the arguments which are in favor and against on tax evasion from an ethical point of view.

The scores varies from 2.38 to 4.01 . Among the other arguments, the strongest argument which is in against of tax evasion is, "tax evasion is ethical if everyone is doing it". This indicates that people do not perceive tax evasion as ethical even if everyone in the country do it. They accept their liability to pay taxes even the others do not pay taxes.

In addition, the next strongest argument which is in against of tax evasion is, "Tax evasion is ethical even if a large portion of money collected is spent on projects that do benefit me". Tax evasion is not considered as ethical, even if the tax payer does not get benefits out of the tax paid.

Moreover, another stronger argument which is in against of tax evasion is, "Tax evasion is ethical if a large portion of money collected is spent on projects that do not benefit me". This indicates that tax evasion is not considered as ethical if the tax money collected is spent projects that do not directly generate any benefits to the tax payer.

In contrast, when considering about the arguments which are in favor of tax evasion, the strongest argument which is in favor of tax evasion is, tax evasion is ethical if a large portion of the money collected is wasted. People try to evade taxes if they oversee that the tax collected is wasted by government by investing that money in inefficient and ineffective activities. In that situation they perceive tax evasion as ethical 
since the money collected as tax is wasted without investing in that money in activities that will benefit whole or majority of the society.

Apart from that, the results also suggest that tax evasion is considered as ethical, if a significant portion of money collected winds up in the pockets of corrupt politicians or their families and friends. This is the argument which is ranked as second strongest which is in favor of tax evasion. When the tax collected is used by politicians for their personal use, tax payers do not perceive any benefit out of tax paid by them. They do not like to pay taxes from the income that they earned to the government if that money is used by the corrupted politicians for their benefit. Therefore, in such a situation people perceive tax evasion as ethical.

Moreover, another argument which in favor of tax evasion from an ethical point of view is, tax evasion is ethical if the tax system is unfair. A good tax system should be fair for each and everyone in the society. If it is not fair people do not accept their liability to pay taxes to the government. If the tax system is not designed in a way that is fair, people try to evade taxes and they perceive it as ethical.

\subsubsection{Gender and ethical perspective towards tax evasion}

The ethical perceptive towards tax evasion has been analyzed based on the gender. Independent sample t-test was used to analyze the data based on the gender. When considering the gender composition of the respondents, majority of the respondents are male. As a percentage it is $53 \%$. $47 \%$ of the total respondents are female.

The results of breakdown of mean scores for gender indicates that there is no any significant difference between men and women more on ethical perspective towards tax evasion. Both men and women are opposed to tax evasion. This result is in consistent with the results of some previous studies (Roxas \& Stoneback, 2004; Andrew \& Costa, 1994; Swaidan, Vitell, Gregory , \& Gilbert, 2006).

However, even the overall results indicate that there is no significant difference between men and women on ethical perspective towards tax evasion, when considering the arguments individually, in some situations there are significant differences between men and women on ethical perspective towards tax evasion. Men are more opposed to tax evasion than women in the situations of, engaging in tax evasion if a large portion of money collected is spent on projects that do not benefit the tax payer 
and, if the probability of getting caught is low. Only for these two arguments men are significantly opposed to tax evasion than women. In all other arguments, there is no significant difference between the ethical perception of men and women towards tax evasion.

\subsubsection{Age and ethical perspective towards tax evasion}

When considering about the age groups of the respondents, majority of the respondents are in the age group of 2025 . As a percentage it is, $54 \%$. Moreover, $24 \%$ from the total respondents are in the age group of $>30$ and $22 \%$ of the respondents are in the age group of $26-$ 30.

The results of the analysis indicate that three age groups that have been considered in this study (20-25, 26-30 and $>30$ ), has same ethical perspective towards tax evasion. All three age groups' perception towards tax evasion is considerably the same and there are no any significant differences between their perceptions. This result is different from the results of the other studies. Since some of the previous studies suggest that people become ethical with the age hence, tax evasion is perceived as unethical in older age groups rather than within younger age groups (McGee \& Sheldon, Ethics, Tax Evasion, Gender and Age, 2007; Durwood \& King, 1992).

\subsubsection{Marital Status and ethical perspective towards tax evasion}

The analysisof the marital status of the respondents indicates that $70 \%$ of the respondents are single and $30 \%$ of the respondents are married.

The results were broken down based on the marital status with the aim of identifying whether the marital status has an impact on the ethical perspective towards tax evasion. Independent sample t-test was incorporated to analyze the data. The results of this analysis indicate that there is no significant difference between mean scores for each argument on tax evasion based on the marital status. Both married and unmarried people have same ethical perspective towards tax evasion.

However, when considering about the arguments individually, in some situations there are significant differences in ethical perspective towards tax evasion between unmarried people and married people. In the situation of perceiving tax evasion as ethical if a large portion of the money collected is wasted, unmarried people are more opposed to that statement than married people. When considering about the mean value for this statement, this is an argument which is in favor of tax evasion. Married people consider evading taxes in this situation more ethical than the unmarried people. 
Furthermore, more unmarried people perceive tax evasion as unethical if a large portion of money collected is spent on projects that they morally disapprove of than the married people.

In contrast, married people are signifi cantly more opposed to tax evasion even if a large portion of money collected is spent on projects that do benefit them, if some of the proceeds go to support a war that they consider to be unjust and even if tax evasion means that if I pay less, others will have to pay more.

\subsubsection{Academic qualifications and ethical perspective towards tax evasion}

Majority of the respondents in the sample are undergraduates. As a percentage, undergraduates' representation in the analyzed data set is, $50 \%$. Rest of the respondents fall in to post graduate category or graduate category. Percentage of their representation in the analyzed data is, $28 \%$ and $22 \%$ respectively.

The results were broken down based on the academic qualifications with the aim of identifying whether the academic qualification has an impact on the ethical perspective towards tax evasion. One way ANOVA test was employed to analyze the data.

The results of the analysis indicate that in some situations there are no any significant difference in mean scores.
No any significant differences were identified for the arguments except tax evasion is ethical if the tax system is unfair and tax evasion is ethical if some of the proceeds go to support a war that considers to be unjust.

Tax evasion is ethical if the tax system is unfair, is one of an argument which is in favor of tax evasion from an ethical point of view. When considering the three groups of undergraduates, post graduates and others (all most consists of graduates), post graduates are most opposed with this statement than the other two groups.

Furthermore, when considering about the argument of tax evasion is ethical if some of the proceeds go to support a war that considers to be unjust, people who are in the other group are more in opposed with this arguments than the undergraduates and post graduates. Undergraduates consider tax evasion is ethical if some of the proceeds go to support a war that considers to be unjust as the mean score of undergraduates for this statement is, 2.94 .

\subsubsection{Major of study and ethical perspective towards tax evasion}

The analysis of the major of study of the respondents indicates that majority of the respondents are from accounting field. When considering about the percentage of the respondents; $52 \%$ 
have studied or still studying in accounting field, $23 \%$ of the respon dents are from finance filed, $12 \%$ are from human resource files, $8 \%$ are from marketing filed, and 5\% falls under other category. Respondents who fall within the other category are from the files of law, business technology, and business administration.

The results indicates that out of 15 statements the mean scores are not significantly different for 12 statements. Only for three arguments there are significant differences in mean scores. For the three arguments of tax evasion is ethical if the tax system is unfair, tax evasion is ethical even if most of money collected is spent wisely and tax evasion is ethical if a significant portion of money collected winds up in the pockets of corrupt politicians or their families and friends people who fall in to other category are more opposed than the others.

\section{Conclusion}

\subsection{Conclusion}

This study made an attempt to determine the extent to which tax evasion is considered as ethical in Sri Lanka, identify the strongest arguments that are there in favor and against on tax evasion from an ethical perspective and finally to analyze tax evasion based on several demographic characteristics. Out of the 120 sample that was selected and sent the questionnaire, 100 usable responses were selected. The final result of the study was obtained through analysis of the data that through SPSS.

The overall result of the study indicate that Sri Lankans do not perceive tax evasion as ethical. There are three main arguments, which against the tax evasion can be listed as; tax evasion is ethical if everyone is doing it, tax evasion is ethical even if a large portion of money collected is spent on projects that do benefit me and tax evasion is ethical if a large portion of money collected is spent on projects that do not benefit me. Out of the these three arguments the strongest arguments which is against tax evasion is, tax evasion is ethical if everyone is doing it. The results indicate that engage in tax evasion if everyone is doing is, never considered as ethical.

Even though the overall results indicates that tax evasion is not perceive as ethical, when considering the each arguments individually, there are some situations where tax evasion is perceived as ethical. The main three arguments which are in favor of tax evasion are; tax evasion is ethical if the tax system is unfair, tax evasion is ethical if a significant portion of money collected winds up in the pockets of corrupt politicians or their families and friends and tax evasion is ethical if a large portion of the money collected is wasted. Out of the these three arguments 
the strongest arguments which is in favor of tax evasion is, tax evasion is ethical if the tax system is unfair

Furthermore, when considering about the different demographic factors of gender, age, marital status, academic qualification and major of study, the overall results under each demographic category suggest that all the people are opposed to tax evasion irrespective of the fact that they include in different demographic category. None of analysis conducted under each of the above demographic characteristics suggest that people perceive tax evasion as ethical. Furthermore, people who have knowledge on taxation are opposed to tax evasion where as people who do not have knowledge on taxation do not perceive tax evasion either as ethical or unethical.

Finally, tax evasion is not perceived as ethical. The strongest argument which is in against of tax evasion is, tax evasion is ethical if everyone is doing it. On the other hand the strongest argument which is in favor of tax evasion is, Tax evasion is ethical if a large portion of the money collected is wasted. Irrespective of the different demographic characteristics all the people are opposed to tax evasion.

\subsection{Recommendations}

Based on the findings of this study following recommendations can be taken in to consideration of the responsible parties.

- Among the other factors that lead the people to engage in tax evasion, wasting the money collected as tax can be identified as the man factor. Therefore, policy makers should make decision to invest the tax revenue collected in worthy activities that will generate benefits to the society as a whole and make the people sense that the tax they paid is not wasted and the benefits that they received is the return of the tax they paid to the government.

- Another strongest factor that lead the people to do tax evasion is, politicians' use of tax collected for their own benefit. Therefore, there should be both appropriate mechanism to ensure that tax revenue cannot be used for anyone's personal use and penalty mechanism to penalize for engage in such activities. Implementation of such mechanism is not sufficient and effective operation of the implemented mechanisms should also ensure.

- Policy makers should ensure that the tax system is fair to everyone in the society. If the people perceive tax system that has been implemented is unfair, they tend to evade taxes. Therefore, it is important to design the tax system in a manner that is fair to everyone in the society. 


\section{References}

Alleyne, P., \& Harris, T. (2016). Antecedents of taxpayers' intentions to engage in tax evasion: evidence from Barbados. Journal of Financial Reporting and Accounting, 15(1), 116154.

Andrew, S., \& Costa, A. D. (1994). Are Women More Ethical than Men? Journal of Business Ethics, 13(11), 859871.

Barnett, J. H., \& Karson, M. J. (1987). Personal Values and Business Decisions: An Exploratory Investiga tion. Journal of Business Ethics, 5 (6), 371-382.

Benk, S., Budak, T., Püren, S., \& Erdem, M. (2015). Perception of tax evasion as a crime in Turkey. Journal of Money Laundering Control, 18(1), 34-51.

Fagbemi, O. T., Uadiale, O. F., \& Noah, O. A. (2010). The Ethics of Tax Evasion: Perceptual Evidence from Nigeria. European Journal of Social Sciences, 17(3).

Gabor, R. (2012). Relation between tax evasion and Hofstede's model. European Journal of, 12(1).

Machinayake, W. (2014). News 1 st. Retrieved December 3, 2017, from http://newsfirst.lk/english/2014/11/dep artment-inland-revenue-says-least$6000-\mathrm{c}$ a s e s - t a x - e v a s i o n identified/61429

McGee, R. W., Aljaaidi , S. K., \& Musaibah , S. A. (2012). The Ethics of Tax Evasion: A Survey of Administrative Sciences' Students in Yemen.
International Journal of Business and Management, 7(16).

McGee, R. (1999). Why people evade taxes in Armenia: a look at an ethical issue based on a summary of interviews. Journal of Accounting, Ethics \& Public Policy, 2(2), 408-416.

McGee, R. W. (1999). An ethical look at paying your 'fair share' of taxes. Journal of Accounting, Ethics \& Public Policy, 2(2), 318-328.

McGee, R. W. (2005). The Ethics of Tax Evasion: A Survey of Romanian Business Students and Faculty. Journal of Balkan and Near Eastern Studies, 130.

McGee, R. W., \& Benk, S. (2011). The ethics of tax evasion: a study of Turkish opinion. Journal of Balkan and Near Eastern Studies, 249-262.

McGee, R. W., \& Bernal, A. (2006). The Ethics of Tax Evasion: A Survey of Business Students in Poland. Florida.

McGee, R. W., \& Bouchra M'Zali, B. (2007). AN EMPIRICAL STUDY OF ATTITUDES TOWARD THE ETHICS OF TAX EVASION IN MALI. Miami: Andreas School of Business.

McGee, R. W., \& Guo, Z. (2007). A survey of law, business and philosophy students in China on the ethics of tax evasion. Society and Business Review, 2(3), 299-315.

McGee, R. W., \& Noronha, C. (2007). The Ethics of Tax Evasion: A Comparative Study of Guangzhou (Southern China) and Macau Opinion. Miami Shores.

McGee, R. W., \& Sheldon , S. R. (2007). Ethics, Tax Evasion, Gender and Age. 
Miami Shores: Barry University.

McGee, R. W., \& Smith, S. R. (2007). Ethics, Tax Evasion, Gender and Age: An Empirical Study of Utah Opinion .

McGee, R. W., \& Tusan, R. (2008). The ethics of tax evasion: a survey of Romanian business students and faculty. The ethics of tax evasion: a survey of Slovak opinion, 575-601.

McGee, R. W., \& Tyler, M. (2007). Tax Evasion and Ethics: A Demographic Study of 33 Countries. Florida.

McGee, R., \& Guo, Z. (2007). A survey of law, business and philosophy students in China on the ethics of tax evasion. Society and Business Review, 2(3), 299315.

McGee, R., Aljaaidi, K. S., \& Musaibah, A. S. (2012). The Ethics of Tax Evasion: A Survey of Administrative Sciences' Students in Yemen. International Journal of Business and Management, 7(16), 1-12.

McGee, W. R., \& Simon, H. S. (2006). The Ethics of Tax Evasion: A Survey of Accounting, Business and Economics Students in Hong Kong. Florida.

Nasadyuk, I., \& McGee, R. W. (2006). TAX EVASION IN UKRAINE: A SURVEY OF OPINION.
Roxas, M. L., \& Stoneback, J. Y. (2004). The Importance of Gender Across Cultures in Ethical Decision-Making. Journal of Business Ethics, 50, 149165.

Sandmo, A. (2005). The theory of tax evasion: a retrospective view. National Tax Journal, 63(2), 643-663.

Sezgin, S., Seyfi, Y., \& Ayyildiz, Y. (2011). The Ethics of Tax Evasion: A Comparative Study of Turkey and Kyrgyzystan. Journal of Applied Business and Economics, 12(3), 75-90.

Swaidan, Z., Vitell, S. J., Gregory, R. M., \& Gilbert, F. W. (2006). Consumer Ethics: The Role of Acculturation in U.S. Immigrant Populations. Journal of Business Ethics, 64(1), 1-16.

The Ceylon Chamber of Commerce. (2017). Government Revenue in Sri Lanka - 11 Insights on 2016 Performance \& 2017 Outlook. Colombo: The Ceylon Chamber of Commerce.

Weeks, W. A., Moore, C. W., McKinney, J. A., \& Longenecker, J. G. (1999). The Effects of Gender and Career Stage on Ethical Judgment. Journal of Business Ethics, 20(4), 301-313. 